Extended Abstract

\title{
Reporting Sustainability in the Oil Sector: Transparency or Greenwashing?
}

\author{
Fabrizio Baldassarre * and Raffaele Campo \\ University of Bari, Department of Business and Law Studies / Largo Abbazia Santa Scolastica 53, \\ Bari, Italy \\ E-Mails: fabrizio.baldassarre@uniba.it; raffaele.campo@uniba.it \\ * Author to whom correspondence should be addressed
}

Accepted: 27 March 2015

\section{Introduction}

Communication is fundamental in marketing. Pinske and Dommisse (2009) have highlighted that it is essential for consumers because they need to be informed about the benefits sprung by their responsible choices in terms of purchases; moreover it is important to improve a company's reputation (Bronn and Vrioni, 2011; Mark-Herbert and Von Schantz, 2007). For this reason sustainability report, considering its communicational function, can be deemed also a tool for marketers.

According to Lozano and Huisingh (2001) sustainability report "is a voluntary activity with two general purposes: (1) to assess the current state of an organisation's economic, environmental and social dimensions, and (2) to communicate a company's efforts and Sustainability progress to their stakeholders. However, these purposes do not consider the time dimension, nor the interactions among the different sustainability dimensions". Obviously companies can choose between two ways: transparency, showing real data, or greenwashing, masking their real attitude and relying on appearance, with risks for reputation and boycott actions (Glazer, Kanniainen and Poutvaara, 2010).

This research is focused on the oil sector, characterized by different sustainability problems, both in an environmental and a social perspective.

\section{Methods}

In order to highlight this issue in the oil sector, a multiple case study approach (Yin, 2009) has been applied. Two of the largest oil company have been chosen, BP and Eni. These companies draft a sustainability report, providing a lot of data and information about their attention to safeguard the 
environment and to have also a positive impact on society. In this study researchers have compared these two cases, spotlighting the controversies which sometimes are stressed in the public opinion. Researchers have analyzed these two companies reports and then they have compared the information gathered from this document to their image.

\section{Results and Discussion}

The analysis of these companies' sustainability report has pointed out a deep commitment to protect environment and also to be responsible from a social point of view. In the following table, for example, there is the list of some of the indicators used in Eni's report.

Table 1. Some of the sustainability indicators used by Eni.

\begin{tabular}{|c|c|}
\hline Area & Main indicators \\
\hline People & $\begin{array}{c}\text { Training hours on safety, Safety expenditures, OHSAS } 18001 \\
\text { certifications, Health and Hygiene expenditures, Employees (total), } \\
\text { Employees (women), Women senior managers, Satisfaction of } \\
\text { participants. }\end{array}$ \\
\hline Environment & $\begin{array}{c}\text { ISO } 14001 \text { certifications, ISO } 50001 \text { certifications, EMAS } \\
\text { registrations, Total systems audit, External certifications bodies, } \\
\text { Environmental expenditures, CO2 emissions, Indirect CO2 emissions } \\
\text { from sales of products, Net consumption of primary resources, } \\
\text { Nitrogen Oxide emissions, Sulphur Oxide emissions, Total water used, } \\
\text { Total recycled or reused water, Waste from reclamation activities, } \\
\text { Waste management expenditures. }\end{array}$ \\
\hline Local development & $\begin{array}{l}\text { Total spending for the territory, Interventions on the territories from } \\
\text { agreements, conventions and PSA by category. }\end{array}$ \\
\hline Stakeholders & $\begin{array}{c}\text { Eni customer satisfaction score, Suppliers used, Overall distributed net } \\
\text { added value. }\end{array}$ \\
\hline Ethics & $\begin{array}{c}\text { Presence of women on the Board of Directors of Eni Group companies, } \\
\text { Hours of training on human rights, Suppliers subjected to qualification } \\
\text { procedures including screening on human rights, SA8000 audits carried } \\
\text { out. }\end{array}$ \\
\hline Innovation & $\begin{array}{c}\text { R \& D expenditures net of general and administrative costs, Personnel } \\
\text { employed in R \& D activities. }\end{array}$ \\
\hline
\end{tabular}

In spite of this, this company has been accused to produce pollution in Nigeria, causing health problems for the local communities, but also to be irresponsible with workers. Also BP presents a report full of information about its sustainable initiatives but, at the same time, it has been found guilty because the damages created near the Gulf of Mexico in 2010. 


\section{Conclusions}

The analyzed cases have shown that sustainability report can be important in a marketing communication strategy but, at the same time, it is not a guarantee of truth. This shows that it is not a perfect tool for communication: it is necessary to research the possible ways to integrate information about environment and society in the balance sheet. Another reflection is relative to the importance of communicating with transparency: greenwashing could represent a problem also from a marketing point of view because it implies the worsening of the company's reputation.

\section{References}

1. Bronn, P.S.; Vrioni, A.B. Corporate social responsibility and cause-related marketing: an overview. International Journal of Advertising 2011, 20, 207-222.

2. Glazer, A., Kanniainen, V., Poutvaara, P. Firms' ethics, consumer boycotts, and signalling. European Journal of Political Economy 2010, 26, 340-350.

3. Lozano, R., Huisingh, D. Inter-linking issues and dimensions in sustainability reporting. Journal of Cleaner Production 2011, 19, 99-107.

4. Mark-Herbert, C.; Von Schantz, C. Comunicating corporate social responsibility- Brand management. Electronic Journal of Business Ethics and Organization Studies 2007, 12, 4-11.

5. Pinske, J.; Dommisse, M. Overcoming barriers to sustainability: an explanation of residential builder's reluctance to adopt clean technologies. Business Strategy and the Environment 2009, 18, 515-527.

6. Yin, R.K. Case study research: design and methods. Sage Publications: Thousand Oaks, USA, 2009.

(C) 2015 by the authors; licensee MDPI and ISIS. This abstract is distributed under the terms and conditions of the Creative Commons Attribution license. 